\title{
nature
}

\section{Don't blame NASA alone for Mars mission failures}

While the spotlight has been focused on mistakes by US space engineers and managers for the loss of recent Mars-bound spacecraft, others share responsibility. This includes those who have set unrealistic goals for the agency.

ए ght years into his tenure as the longest-serving administrator for the US space agency NASA, Dan Goldin has hit a bad patch of road. Last year's embarrassing Mars failures have subjected his cherished 'better, faster, cheaper' philosophy to second-guessing, and the administrator and his deputies have responded somewhat defensively by tallying up the agency's win-loss record since 1992: 146 payloads launched, only 10 lost. See? The strategy works.

They should relax. No one, least of all the panel led by aerospace executive Thomas Young that delivered last week's critique of the Mars programme, is calling for a return to big, infrequent missions (see page 535). And most people are willing to accept some additional risk to boost the flight rate. Most would also agree that Goldin is a visionary, and that his transformation of NASA has been truly revolutionary. But he is also a politician. And NASA tends to run into trouble when politics is injected into a business that is difficult even under the best circumstances.

It would be wrong to say the Mars programme was politically motivated. The planet's similarity to Earth and the existence of water (certainly in the past, maybe under the surface today) make it a compelling scientific destination. But the 1996 claim of fossils in a Martian rock added a public relations (hence political) dimension to the programme that hadn't been there before. This, along with Goldin's eagerness to prove that his employees could do more with less, are what led to the downfall.

The Young report treats this NASA pressure on the Jet Propulsion Laboratory (JPL) delicately: "NASA Headquarters thought it was articulating programme objectives, mission requirements, and constraints. JPL management was hearing these as non-negotiable programme mandates." This may be letting NASA off the hook too easily. The political realities of the Mars programme were not misinterpreted by the JPL engineers and scientists in the trenches. They understood that they could not ask for more money, nor could they radically 'descope' their missions. Their only choice was to sigh and accept more risk. That, or resign.

Goldin showed class last week by taking the dejected JPL Mars team to dinner, then repeating his mea culpa in public: "I pushed too hard, and in doing so stretched the system too thin."

Others have yet to admit their share of the blame. The White House, which scrutinizes and approves every NASA budget request, said not a word last week. James Sensenbrenner, who chairs the agency's authorizing committee in the House of Representatives, issued his own defensive statement pointing out that Congress has given NASA more money than it requested for space science in five of the past six years.

Do Goldin and those who determine his funding really understand where they went wrong? In the case of the Mars programme, probably yes. But it will be interesting to see how they respond to another current agency project that has the same disturbing combination of engineering complexity, too few resources, politics that constrain project managers' decisions, and workers just trying to make the best of a bad situation. It's called the International Space Station.

\section{Taking the initiative}

Two new sections of Nature should help to keep readers informed and up to date on important areas of science.

$D_{\mathrm{k}}^{\mathrm{u}}$ ublications whose staff sit back and wait for the world to come knocking on their door are likely to be short-lived. Nevertheless, Nature could easily fill its gradually increasing number of pages every week by being reactive rather than proactive. Events would happen and journalists would write about them; we would go on publishing the best of what we receive in the form of original papers, and News and Views authors would explain them.

But that philosophy would do less than justice to our readers, who deserve more by way of editorial initiative. Nature has never lacked proactivity. But this week sees two significant further steps in that spirit: the launches of the News Features and Nature Insight sections (see pages 538 and 631, respectively). Nature already aims to publish overviews that are authoritative, timely, dynamic and, above all, accessible. Our News Features represent an enhancement of our regular journalistic coverage that is intended to help meet this goal.

The Nature Insight section, to be published every month, will bring together a collection of articles covering many aspects of a timely subject, in the form of commentaries and review articles written by acclaimed scientists in the field. As the boundaries between disciplines are blurring - for example, with physicists trying to understand intricate details of cells and biologists modelling global signalling networks - there has never been a greater need to understand specialist issues across the expanse of biology and the physical sciences. Claiming to provide a one-stop shop on any subject would smack of hubris, but that is what we aspire to. The reviews are presented in a style designed for maximum clarity, with special attention to annotated schematics to aid understanding of the text, and boxes containing information for the specialist or background information for the general reader. Thus, in contrast to traditional review articles, we hope that these collections of overviews will entice readers not already closely involved in the area of research.

In this issue we have focused both the Nature Insight and the News Feature on the same topic. We hope readers will enjoy the complementarity of these approaches. 